\title{
CASE STUDY OF CONGENITAL ANOMALIES OF THE UPPER LIMB IN REFERENCE AMBULATORY CARE FACILITY
}

\section{ESTUDO DE CASOS DE ANOMALIA CONGÊNITA DO MEMBRO SUPERIOR EM SERVIÇO AMBULATORIAL DE REFERÊNCIA}

\author{
Henrique de Barros Pinto Netto ${ }^{1,2}$, Antônio Pedro Pais², Simone Costa Vitorio ${ }^{2}$, Renata Brandão ${ }^{2}$, Aline Aparecida Depianti Moreira ${ }^{2}$, \\ Luiz Raphael Molinaro Neto ${ }^{2}$
}

1. Hospital Federal da Lagoa, Department of Orthopedics and Traumatology, Rio de Janeiro, RJ, Brazil.

2. Hospital Federal da Lagoa, Department of Hand Surgery, Rio de Janeiro, RJ, Brazil.

\section{ABSTRACT}

Objective: The epidemiological profile of congenital anomalies of the upper limbs (CAULs) is of major relevance to monitoring and planning. A study of this profile may reveal if there is prevalence of some specific type of malformation in comparison to a more comprehensive epidemiological sample. The Latin American Collaborative Study of Congenital Malformations (ECLAMC) has an extensive database, providing an excellent source of comparison. This study aims to evaluate the epidemiological profile of CAULs at the hand surgery department of the Hospital Federal da Lagoa $(\mathrm{HFL})$ in Brazil, and compare it to the ECLAMC data. Methods: We conducted a retrospective analysis of patients who underwent treatment at the pediatric outpatient hand surgery clinic. The sample universe consisted of 126 patients (4 of these patients presented with 2 simultaneous anomalies), totaling 130 malformations. Results: The results demonstrated that the comparable pathologies have significantly similar incidence rates. It is worth noting the polydactylies (pre- and post-axial), where the percentile of incidence in the ECLAMC was higher. Conclusion: This study showed that the epidemiological profile of patients who underwent treatment at this hospital was equivalent to that found in the ECLAMC database. Level of evidence III, Retrospective epidemiological study.

Keywords: Epidemiology. Upper extremity. Congenital abnormalities. Hand deformities.

\section{RESUMO}

Objetivo: O perfil epidemiológico das anomalias congênitas dos membros superiores (ACMS) é de suma relevância para monitoramento e planejamento. Um estudo nesse sentido pode revelar se há prevalência de algum tipo específico de malformação em comparação com amostra epidemiológica mais abrangente. O Estudo Colaborativo Latino Americano de Malformação Congênita (ECLAMC) tem uma extensa base de dados, que serve como excelente fonte de comparação. Este estudo tem por escopo avaliar o levantamento da casuística das ACMS no serviço de cirurgia da mão do Hospital Federal da Lagoa (HFL) e compará-la aos dados do ECLAMC. Métodos: Foi realizada uma análise retrospectiva dos pacientes atendidos no ambulatório infantil de cirurgia da mão. O universo amostral foi de 126 pacientes (sendo que 4 pacientes apresentavam 2 anomalias simultaneamente), totalizando 130 malformações. Resultados: Demonstrou-se que as patologias que puderam ser comparadas têm percentuais de incidência significativamente semelhantes. Cabe ressalvar as polidactilias (pré e pós-axiais), em que o percentil de incidência no ECLAMC foi maior. Conclusão: Este estudo evidenciou que o perfil epidemiológico dos pacientes atendidos neste hospital foi equivalente ao encontrado na base de dados do ECLAMC. Nível de evidência III, Estudo epidemiológico retrospectivo.

Descritores: Epidemiologia. Membros superiores. Anormalidades congênitas. Deformidades da mão.

Citation: Pinto Netto HB, Pais AP, Vitorio SC, Brandão R, Moreira AAD, Molinaro Neto LR. Case study of congenital anomalies of the upper limb in reference ambulatory care facility. Acta Ortop Bras. [online]. 2018;26(5):325-7. Available from URL: http://www.scielo.br/aob.

\section{INTRODUCTION}

Congenital anomalies affect from 1 to $3 \%$ of live births and about $10 \%$ of these children have abnormalities of the upper limbs. The incidence of congenital anomalies has not changed much over the last decade. Most occur spontaneously or due to genetic inheritance and few are attributed to teratogens. ${ }^{1}$

Epidemiological data for congenital anomalies of the upper limb (CAULs) are significant for planning, monitoring, and research. Research on etiology and prevention depends on high-quality epidemiological data. ${ }^{2}$
In Latin America, there is a universal database for recording all congenital malformations; the program is named the Latin American Collaborative Study of Congenital Malformation (ECLAMC).

The ECLAMC is a clinical and epidemiological research program for developmental anomalies that works with hospital births in Latin American countries. Therefore, this is a program for research on risk factors for malformations with a case-control methodology. Ideally, a classification for CAUL should incorporate the primary etiology and evaluate prognosis and treatment planning, besides

All authors declare no potential conflict of interest related to this article. 
adopting a universal language for discussion. ${ }^{3}$ In 1964, Swanson proposed a new classification system, aimed at hand surgeons and regarded as anatomical and clinical, which indicates the type of primary embryogenic defect.

\section{OBJECTIVE}

Evaluating the epidemiological profile of CAULs at the hand surgery service of the Brazilian Federal Hospital of Lagoa (HFL) within the period from May 2015 to October 2017, and comparing it to the incidence of these anomalies in the ECLAMC database.

\section{MATERIALS AND METHODS}

This study has been developed at the hand surgery service of the HFL. Since this is a retrospective study, there was no need for either a Brazilian free and informed consent term (TCLE) or the approval by a Brazilian research ethics committee (CEP). It is worth noticing there is no conflict of interest between researchers regarding this study.

All patients with some CAUL provided with care at the child outpatient hand surgery clinic from May 2015 to October 2017 have been selected for this study. Patients with deformities or lesions acquired after birth or those who had deformities that were not in the upper limbs have been excluded from this study.

The selected patients were grouped according to the Swanson's Universal Classification in order to evaluate the prevalence of each deformity and they were referred for surgical correction of it. After obtaining data in the aforementioned period, the ECLAMC database was accessed to validate the proportions of congenital malformations of the upper limb and their proportions in relation to other research centers.

\section{RESULTS}

The study sample consists of 126 patients with some CAUL, where 4 of them had 2 anomalies simultaneously, totaling 130 malformations. Out of the total sample, $87 \%$ refer to patients with duplication or failure to differentiate the parts according to the classification of the International Federation of Societies for Surgery of the Hand (IFSSH). Patients were separated according to their pathology, as proposed by the Swanson's classification. A total of 126 new patients were registered, out of which there were 9 formation failures (7\%), 55 differentiation failures (42\%), 58 duplication failures (45\%), 6 constriction band syndromes (5\%), and 2 skeletal abnormalities (1\%). (Figure 1) Among these malformations, we observed 34 cases of post-axial polydactyly (27\%), 18 cases of thumb duplication (14.3\%), 17 cases of congenital trigger (13.5\%), 22 cases of syndactyly (17.5\%), 8 cases of camptodactyly (6.3\%), 6 cases of constriction band syndrome (4.8\%), 3 cases of split hand (2.4\%), 4 cases of radial club hand (2.4\%), 3 cases of three phalanges thumb (2.4\%), 3 cases of pre-axial polydactyly (2.4\%), 2 cases of clinodactyly (1.6\%), 2 cases of ulnar club hand (1.6\%), 3 cases of thumb hypoplasia (2.4\%), 1 case of Kirner's deformity $(0.8 \%), 1$ case of arthrogryposis $(0.8 \%), 1$ case of metacarpal synostosis (0.8\%), 1 case of thumb agenesis $(0.8 \%)$, and 1 case of Madelung's deformity (0.8\%). Out of this total number of patients, 71 were men (56.3\%) and 55 were women (43.7\%). (Figure 2) By comparing the records available in the ECLAMC database for some anomalies, it is observed that the proportions of cases with post-axial polydactyly in the study sample are slightly higher than half the proportion registered by the ECLAMC. (Table 1)

By analyzing the demographic and epidemiological profile of the patients under study, it is observed that most of them are men (56.3\%), aged up to 4 years old (84.2\%). (Table 2) As for laterality, a good balance is noticed between the total number of patients having only one side affected and that of patients with both sides affected. (Table 3)

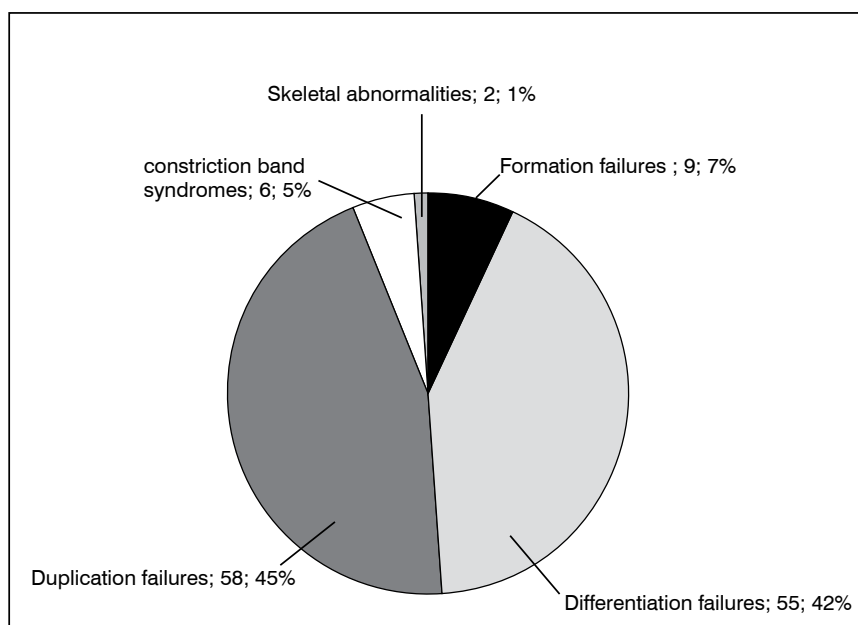

Figure 1. Total number of patients with anomalies diagnosed according to the IFSSH classification.

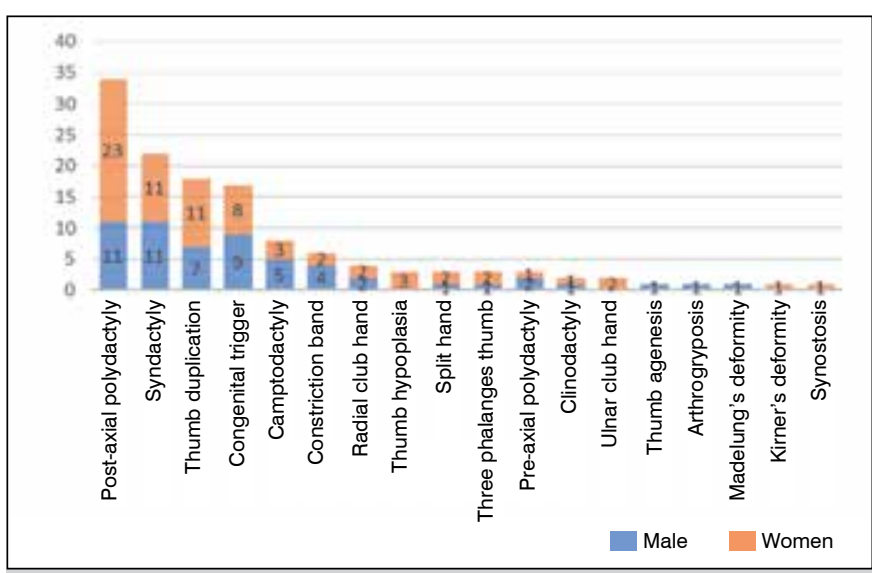

Figure 2. Total number of patients according to sex and anomaly diagnosed.

Table 1. Total number and percentile of patients in the HFL according to the anomaly diagnosed and respective records in the ECLAMC.

\begin{tabular}{c|c|c|c|c}
\hline \multirow{2}{*}{ Type of anomaly } & \multicolumn{2}{|c|}{$\begin{array}{c}\text { Brazilian Federal Hospital of } \\
\text { Lagoa - May/2015-Oct/2017 }\end{array}$} & \multicolumn{2}{c}{$\begin{array}{c}\text { ECLAMC } \\
\text { Lag2-2006 }\end{array}$} \\
\cline { 2 - 5 } & Total & $\%$ & Total & $\%$ \\
\hline Thumb agenesis & 1 & 0.8 & n.a & n.a \\
\hline Arthrogryposis & 1 & 0.8 & n.a & n.a \\
\hline Constriction band & 6 & 4.8 & n.a & n.a \\
\hline Camptodactyly & 8 & 6.3 & n.a & n.a \\
\hline Clinodactyly & 2 & 1.6 & n.a & n.a \\
\hline Madelung's deformity & 1 & 0.8 & n.a & n.a \\
\hline Kirner's deformity & 1 & 0.8 & n.a & n.a \\
\hline Thumb duplication & 18 & 14.3 & n.a & n.a \\
\hline Congenital trigger & 17 & 13.5 & n.a & n.a \\
\hline Thumb hypoplasia & 3 & 2.4 & n.a & n.a \\
\hline Split hand & 3 & 2.4 & 52 & 0.4 \\
\hline Radial club hand & 4 & 3.2 & 542 & 4.4 \\
\hline Ulnar club hand & 2 & 1.6 & n.a & n.a \\
\hline Three phalanges thumb & 3 & 2.4 & n.a & n.a \\
\hline Post-axial polydactyly & 34 & 27.0 & 5,600 & 45.6 \\
\hline Pre-axial polydactyly & 3 & 2.4 & 1,216 & 9.9 \\
\hline Syndactyly & 22 & 17.5 & 1,392 & 11.3 \\
\hline Synostosis & 1 & 0.8 & n.a & n.a \\
\hline
\end{tabular}

$\mathrm{n} . \mathrm{a}=$ information not available 
Table 2. Demographic and epidemiological profile of patients in the study sample.

\begin{tabular}{c|c|c}
\hline Variable & Total & $\%$ \\
\hline Sex & 126 & 100.0 \\
\hline Male & 71 & 56.3 \\
\hline Female & 55 & 43.7 \\
\hline Age group & 126 & 100.0 \\
\hline Less than 1 year & 54 & 42.9 \\
\hline 1 to 2 years & 36 & 28.6 \\
\hline 3 to 4 years & 16 & 12.7 \\
\hline 5 years or more & 18 & 14.3 \\
\hline No information & 2 & 1.6 \\
\hline Side affected & 126 & 100.0 \\
\hline Unilateral & 64 & 50.8 \\
\hline Right & 35 & 27.8 \\
\hline Left & 29 & 23.0 \\
\hline Bilateral & 59 & 46.8 \\
\hline No information & 3 & 2.4
\end{tabular}

Table 3. Total number and percentile of patients according to the IFSSH classification of the respective anomaly and the side affected.

\begin{tabular}{c|c|c|c|c|c}
\hline \multirow{2}{*}{ Classification } & \multirow{2}{*}{ Total } & \multicolumn{2}{|c|}{ Unilateral } & \multirow{2}{*}{ Bilateral } & $\begin{array}{c}\text { No } \\
\text { information }\end{array}$ \\
\cline { 3 - 5 } & & Right & Left & & - \\
\hline Part-formation failure & 9 & $2(22.2 \%)$ & $2(22.2 \%)$ & $5(55.6 \%)$ & - \\
\hline Part-differentiation failure & 55 & $18(32.7 \%)$ & $14(25.4 \%)$ & $21(38.2 \%)$ & $2(3.6 \%)$ \\
\hline Duplication & 58 & $14(24.1 \%)$ & $13(22.4 \%)$ & $30(51.7 \%)$ & $1(1.7 \%)$ \\
\hline Hypergrowth & - & - & - & - & - \\
\hline Hypogrowth & - & - & - & - & - \\
\hline $\begin{array}{c}\text { Constriction band } \\
\text { syndrome }\end{array}$ & 6 & $3(50.0 \%)$ & $1(16.7 \%)$ & $2(33.3 \%)$ & - \\
\hline $\begin{array}{c}\text { Generalized skeletal } \\
\text { anomalies }\end{array}$ & 2 & $1(50.0 \%)$ & - & $1(50.0 \%)$ & - \\
\hline
\end{tabular}

\section{DISCUSSION}

Understanding the epidemiology of a medical condition or a syndrome is paramount for determining its impact on society. The existence of a database on the incidence of CAULs is of major significance for potential determination of their risk factors and the development of comparative studies based on previous analyses. ${ }^{4}$ By comparing the malformations found in our study to the ECLAMC database, we observed that both showed post-axial polydactyly as the most prevalent malformation. This anomaly is included in the Swanson's duplication failures and, according to the literature, it is most commonly found in African and American populations; by comparing our findings to a population study carried out in Stockholm, Sweden, ${ }^{5}$ we noticed that duplication failures rank $3^{\text {rd }}$ in prevalence, something which may corroborate the incidence theory according to ethnicity.

Syndactyly appears as the second most prevalent malformation in our data, as well as in the ECLAMC data. This group also included those who had syndromes which may occur along with this anomaly (Poland, acrosyndactyly, symbrachydactyly).

In this study, thumb duplication appears as the $3^{\text {rd }}$ most frequent anomaly, similarly to the ECLAMC data, where it appears in $3^{\text {rd }}$ place in terms of prevalence. Although termed as duplication failures in the Swanson's classification, there is a hypothesis that this anomaly is not a real duplication; both duplicate components are smaller than a normal thumb, so this would fit more appropriately as a differentiation failure. ${ }^{1}$

This study poses as a drawback the fact that we have a small sample of patients, due to the short period of existence of the specific outpatient clinic for CAULs. For the continuity of this research, this bias will be minimized.

\section{CONCLUSION}

The epidemiological profile of the patients provided with care at this hospital was equivalent to that found in the ECLAMC databases, evidencing the same pattern of anomalies found in other Latin American countries.

AUTHORS' CONTRIBUTIONS: Each author made significant individual contributions to this manuscript: HBPN (0000-0001-9012-9999)*, APP (00000003-0405-5175)* and RBA (0000-0002-1679-8876)*: Substantial contribution to the conception or design of the work, acquisition, analysis or interpretation of data for the work. SCV (0000-0002-1068-0199)* and LRMN (0000-0001-7712-2215)*: Active participation in the discussion of results. RBA and AADM (0000-0002-6659-2112)*: Writing of the work or critical review of its intellectual content. HBPN, APP, RBA, AADM, SCV and LRMN: Review and approval of the final version of the manuscript. *ORCID (Open Researcher and Contributor ID).

\section{REFERENCES}

1. Wolfe SW, Hotchkiss RN, Pederson WC, Kozin SH. Green's operative hand surgery. 6th ed. Churchill Livingstone: Elsevier; 2011.

2. Giele H, Giele C, Bower C, Allison M. The incidence and epidemiology of congenital upper limb anomalies: a total population study. J Hand Surg Am. 2001;26(4):628-34

3. De Smet L. Classification for congenital anomalies of the hand: the IFSSH classification and the JSSH modification. Genet Couns. 2002;13(3):331-8
4. Goldfarb CA, Wall LB, Bohn DC, Moen P, Van Heest AE. Epidemiology of congenital upper limb anomalies in a Midwest United States population: an assessment using the Oberg, Manske, and Tonkin classification. J Hand Surg Am. 2015;40(1):127-32.

5. Ekblom AG, Laurell T, Arner M. Epidemiology of congenital upper limb anomalies in 562 children born in 1997 to 2007: a total population study from Stockholm, Sweden. J Hand Surg Am. 2010;35(11):1742-54 